\title{
Effect of newer insecticides against pod fly, Melanagromyza obtusa (Malloch) on long duration pigeon pea
}

\author{
Srujana Y. and Ram keval ${ }^{1}$ \\ ${ }^{1}$ Department of Entomology \& Agril. Zoology, Institute of Agricultural Sciences B.H.U., Varanasi, India
}

\begin{abstract}
The tur pod fly, Melanagromyza obtusa was found to be predominant during the year of experimentation and it causes significant economic losses in the grain yield of long duration pigeon pea BAHAR. During the year of experimentation, the three application of Thimethoxam 25 WG@ $75 \mathrm{~g}$ a.i. / ha., Fipronil25EC@8g a.i./ha., Thiacloprid240 SC@75 g a.i. /ha., Imidacloprid17.8SL@20 g a.i. /ha., Acetamiprid20SP@20 g a.i./ha.,Dimethoate@30 g a.i. /ha., were done. First applied at 50\% flowering stage, second applied 15 days after first spraying and last 15 days after second spraying gave the best protection against pod fly. The per cent pod damage by pod fly was minimum is Thimethoxam 25 WG@75 g a.i. /ha treated plot, during the year of investigation. Next to this is Fipronil25EC@8ga.i./ha. Thimethoxam 25 WG@75 g a.i. /ha treated plot gave the lowest per cent grain damage followed by Fipronil 25 EC@8 g a.i. /ha.

Keywords : Bahar, pod fly
\end{abstract}

\section{Introduction}

Pigeonpea [Cajanuscajan (L.) Millsp.] is the most important delicious 'Dhal' (pulse) of the India. After gram, arhar is the second most important pulse crop of India, which contributes about 90 per cent of the world's pigeonpea production Muller et al ${ }^{[1]}$ In India, the area of pigeonpea is 3.53 million hectare and production 2.55 million tons and productivity is $723 \mathrm{~kg} / \mathrm{ha}$ in 2009-10. (Source: Directorate of Economics and Statistics, Ministry of Agriculture, Government of India.) The productivity of pigeonpea has not increased considerably during last decade in India. The damage caused by insect pests is one of the major reasons of low productivity. Sachan et $a l .{ }^{[2]}$ have reported that pigeonpea is attacked by nearly 250 species of insect worldwide belonging to 8 orders and 61 families though relatively few cause serious yield losses. The key pests of long duration pigeonpea include gram pod borer Helicoverpaarmigera(Hub.), legume pod borer Marrucavitrata (Fiabricius) and tur pod fly Melanagromyzaobtusa (Malloch). Others such as tur pod bug Clavigrallagibbosa(Spinola), blue butter fly Lampidesboeticus(L.) and plume moth Exelastisatomosa (Walsingham) are also potential pests and occasionally cause significant grain yield losses in long duration pigeonpea. In a survey conducted by ICRISAT, Melanagromyza obtusa (Malloch) was reported to damage 22.5 per cent pigeon pea pods in north India, 21 per cent in central India and 13.2 per cent in South India, Lateef and Reed ${ }^{[3]}$. The annual loss of pigeon pea production due to pod fly alone has been estimated to the extent of 25 to 30 per cent in U.P. Lal and Yadav ${ }^{[4]}$

\section{Methodology}

The long duration pigeonpea variety BAHAR, which is commonly cultivated in this area was grown in plots of 5 rows, 4 meters following row to row and plant to plant spacing of $75 \mathrm{~cm}$ and $10 \mathrm{~cm}$ respectively, during the 2010-2011. The crop was grown following the normal agronomic practices in "Randomized Block Design" with three replications and seven treatment including control. The crop was sowed on $28^{\text {th }}$ August during 2010 and harvested on $10^{\text {th }}$ April 2011. The spray mixture of each treatment was prepared by mixing of required quantity of the insecticides formulations in water to make it equivalent to 600 litres / ha. The spray mixtures were freshly prepared for each treatment. The spraying was done by ASPEE foot sprayer fitted with cone type nozzle. The sprayer was duly calibrated with water for the application rate of 600 litres spray mixture / ha. The applications of the treatment started with the flowering initiation stage of the crop and were applied thrice at the interval of 15 days during the experimentation. The first spray was done at 50 per cent flowering stage and the next was 15 days after the first spraying. In control, the plain water was sprayed. The details about the insecticides are given in Table1. Insecticides were applied during early hours of the day where wind velocity was suitable for spraying. This helped in avoiding the drift of spray fluid to the adjacent plots. Due care was also taken to spray each plot uniformly and the sprayer was thoroughly washed after spraying of each insecticides.

\section{Results}

\subsection{Effect of various treatments on per cent grain damage by tur pod fly}

The difference in per cent grain damage due to treatments applied showed significant and data are given in table 2 . The range of per cent grain damage was (6.77\%) in $\mathrm{T}_{5}$ i.e. Thimethoxam $25 \mathrm{WG} @ 75 \mathrm{~g}$ a.i. /ha 
to (11.73\%) in $\mathrm{T}_{2}$ Dimethoate $30 \mathrm{EC} @ 20 \mathrm{~g}$ a.i. /ha. All the treatments were found superior over control with respect to per cent grain damage. The relative performance of difference insecticides was found in order of Thimethoxam25 WG@75 g a.i. /ha > Fipronil25 EC@8 g a.i. /ha >Thiacloprid240 SC @75 g a.i. /ha > Acetamaprid 20 SP@20 g a.i. /ha > Imidacloprid17.8 SL@20 g a.i. /ha > Dimethoate30 EC @ 30 g a.i. /ha. Thimethoxam 25 WG @ $75 \mathrm{~g}$ a.i. /ha treated plot gave the lowest grain damage i.e.6.77\% followed by Fipronil 25 EC @ $8 \mathrm{~g}$ a.i. /ha (7.48\%) then Thiacloprid 240 SC @ $75 \mathrm{~g}$ a.i. /ha (8.52\%). The per cent grain damage in control was (15.13\%). (Table 2).

\subsection{Effect of various treatments on per cent pod damage by tur pod fly}

The treatments applied showed significant differences in the per cent pod damage by pod fly and data are given in table 2. The per cent pod damage ranged from 17.33\% in Thimethoxam 25 WG @ $75 \mathrm{~g}$ a.i /ha to $26.66 \%$ in Dimethoate 30 EC @ 30 g a.i. /ha. While in control plot the damage was 33.33\%. All the treatments were found to be superior over control with respect to per cent pod damage. The relative performance of various insecticides was found in order of Thimethoxam25 WG@75 g a.i. /ha > Fipronil25 EC@8 g a.i. /ha > Thiacloprid240 SC@75 g a.i. /ha > Imidacloprid17.8 SL@20 g a.i. /ha > Acetamiprid20 SP@20 g a.i. /ha > Dimethoate30 EC@30g a.i. /ha. (Table 2).Thimethoxam25 WG@75g a.i. /ha treated plot gave the lowest percentage damage i.e.17.33\% followed by Fipronil 25 EC @ $8 \mathrm{~g}$ a.i. /ha (17.66\%) and then Thiacloprid 240 SC@ 95 g a.i. /ha (20.33\%), whereas in control plot damage due to pod fly was (33.33\%)

\subsection{Effect of various treatments on grain yield}

The treatments applied showed significant differences in grain yield, whose data are given in Table 2. The yield ranged from $9.53 \mathrm{q} / \mathrm{ha}$ in $\left(\mathrm{T}_{2}\right)$ i.e. Dimethoate $30 \mathrm{EC} @ 30 \mathrm{~g}$ a.i./ha to $13.88 \mathrm{q} / \mathrm{ha}$ in $\left(\mathrm{T}_{5}\right)$ i.e. Thiacloprid 240 SC@75 g a.i. /ha. It is clear from the Table 2 that in case of treatment performance the grain yield was found in order to $\left(\mathrm{T}_{2}\right)$ Dimethoate $30 \mathrm{EC} @ 30 \mathrm{~g}$ a.i./ha $(9.53 \mathrm{q} / \mathrm{ha})<\left(\mathrm{T}_{3}\right)$ Fipronil 25 EC @ $8 \mathrm{~g}$ a.i. /ha $(10.66 \mathrm{q} / \mathrm{ha})<\left(\mathrm{T}_{1}\right)$ Acetamiprid $20 \mathrm{SP} @ 20 \mathrm{~g}$ a.i. /ha $(11.77 \mathrm{q} / \mathrm{ha})<\left(\mathrm{T}_{4}\right)$ Imidacloprid 17.8 SL @ $20 \mathrm{~g}$ a.i. /ha $(12.00 \mathrm{Kg} / \mathrm{ha})<\left(\mathrm{T}_{6}\right)$ Thimethoxam $25 \mathrm{WG} @ 75$ a.i. /ha. $(12.93 \mathrm{q} / \mathrm{ha})<\left(\mathrm{T}_{5}\right)$ Thiacloprid $240 \mathrm{SC} @ 75 \mathrm{~g}$ a.i. /ha (13.88 q/ha). Where as in the control plot the grain yield was found only $7.66 \mathrm{q} / \mathrm{ha}$. (Table 2)

\section{Discussion}

Treatments applied showed significant difference in the per cent pod and grain damage by pod fly. Treatment, Thimethoxam 25 WG @ $75 \mathrm{~g}$ a.i./ha showed lowest percentage pod damage (17.33\%). This is closely followed by the Fipronil 25 EC @ 8 g a.i. /ha (17.66) and Thiacloprid 240 SC @ 75 g a.i./ha (20.33\%). Pod damage in control plot was $(33.33 \%)$ and this shows that the all the treatments are superior over the control.

Pasqualini et al. ${ }^{[5]}$ have reported that the imidacloprid $17.1 \%$ (Confidor) and $19.6 \%$ (Confidor OTEQ), and thimethoxam (Acta $25 \mathrm{WG}$ ) gave excellent control of grey aphid (Dysaphis plantaginea) and the woolly aphid (Eriosoma lanigerum) in apples.

The percent grain damage by pod fly in control plot was $15.13 \%$. Thimethoxam 25 WG $@ 75$ g a.i. /ha treated plot gave the lowest grain damage i.e. 6.77\% followed by this is Fipronil 5\% SC @100 g a.i./ha (7.43\%) then Thiacloprid 240 SC @ $75 \mathrm{~g}$ a.i. /ha (8.52\%). The highest grain damage was recorded in control (15.13\%) which shows that all treatments are significantly superior over control.

\section{Conclusion}

The tur pod fly Melanagromyza obtusa was found to be predominant during the year of experimentation and it causes significant economic losses in the grain yield of long duration pigeon pea BAHAR. Next to pod fly the second destructive pest was pod bug Clavigralla gibbosa in terms of damage caused to the crop. The lepidopterous borers were not of much economic significance however few individual of Lampides boeticus, Exelastis atomosa, Helicoverpa armigera and Maruca vitrata were also seen in the field

\section{References}

[1] R. A. E. Muller, P. Rao, and S. Rao, Pigeonpea: markets and outlook In: The pigeonpea in Y.L. Nene et al.(Ed), (Wallingford united kingdom C.A.B. International and International Crop Institute for the Semi-Arid Tropics, 1990) 457-479.

[2] J.N. Sachan, C. P. Yadava, R. Ahmad, and G. Katti, 1994. Insect pest Management in pulse crops, In G.S. Dhaliwal and Rarnesh Arora (edds.), Trends in Agricultural insect pest management, ( New Delhi-Commonwealth Publishers) 308-344.

[3] S. S. Lateef, and W. Reed. Survey of insect pest damage in farmer's field in India, International pigeonpeaNewsletter (1), 1981, 2930 .

[4] S. S. Lal, C. P. Yadava, and C. A. R. Dias, Major pest problems of pigeonpea in Uttar Pradesh India. International Pigeonpea Newsletter (1), 1981, 30-31.

[5] E. Pasqualini, S. Civolani, and A. Pollini, Imidacloprid and thimetoxam control the apple aphids, Informatore Agrario. 66 (9), 2010, $67-72$. 
Effect of newer insecticides against pod fly, Melanagromyza obtusa (Malloch) on long duration

Table 1: Relative performance of some newer insecticides on per cent grain and pod damage by pod fly on long duration pigeon pea (Bahar) during 2010-11

\begin{tabular}{|c|c|c|c|c|c|}
\hline \multirow{2}{*}{ S.No. } & \multirow{2}{*}{ Treatments } & \multirow{2}{*}{$\begin{array}{c}\text { Dose } \\
\text { ( g a.i./ha) }\end{array}$} & \multicolumn{2}{|c|}{ Pod fly } & \multirow{2}{*}{ Yield (q/ha) } \\
\hline & & & $\%$ Grain damage & $\%$ Pod damage & \\
\hline 1. & Acetamiprid 20 SP & 20 & $\begin{array}{c}8.87 \\
(17.30)\end{array}$ & $\begin{array}{l}21.66 \\
(27.73)\end{array}$ & 11.77 \\
\hline 2. & Dimethoate & 30 & $\begin{array}{c}11.73 \\
(19.98)\end{array}$ & $\begin{array}{c}26.66 \\
(31.05)\end{array}$ & 9.53 \\
\hline 3. & Fipronil 25 EC & 8 & $\begin{array}{c}7.48 \\
(15.79)\end{array}$ & $\begin{array}{c}17.66 \\
(24.80)\end{array}$ & 10.66 \\
\hline 4. & $\begin{array}{l}\text { Imidacloprid } 17.8 \\
\text { SL }\end{array}$ & 20 & $\begin{array}{c}9.18 \\
(17.62)\end{array}$ & $\begin{array}{l}21.33 \\
(27.48)\end{array}$ & 12.00 \\
\hline 5. & Thiacloprid 240 SC & 75 & $\begin{array}{c}8.52 \\
(16.87)\end{array}$ & $\begin{array}{c}20.33 \\
(26.69)\end{array}$ & $13.88^{\mathrm{H}}$ \\
\hline 6. & $\begin{array}{l}\text { Thiamethoxam } 25 \\
\text { WG }\end{array}$ & 75 & $\begin{array}{c}6.77 \\
(15.04)^{\mathrm{L}}\end{array}$ & $\begin{array}{c}17.33 \\
(24.50)^{\mathrm{L}}\end{array}$ & 12.93 \\
\hline 7. & Control & - & $\begin{array}{c}15.13 \\
(22.18)^{\mathrm{H}}\end{array}$ & $\begin{array}{c}33.33 \\
(35.24)^{\mathrm{H}}\end{array}$ & $7.66^{L}$ \\
\hline & S.Em. \pm & - & 1.04 & 2.07 & \\
\hline & D.at $P=0.05 \%$ & - & 2.54 & 5.02 & \\
\hline
\end{tabular}

Figures in parentheses are arcsine transformed values $\mathrm{L}=$ Lowest,$\quad \mathrm{H}=$ Highest 